\title{
THE EFFECT OF BOILING ON THE NUTRITIVE VALUE OF MILK
}

\author{
BY
}

STANLEY GRAHAM, M.D., AND NOAH MORRIS, M.D.

(From the Department of Paediatrics, Glasgow University, and the Biochemical Laboratory, Royal Hospital for Sick Children, Glasgow.)

It is admitted on all sides that untreated milk, no matter of what quality, may act as a carrier of infective material. In this connexion it should be emphasized that the tubercle bacillus is but one of the pathogenic organisms liable to be so transmitted. $\mathbf{S m i t h}^{3}$ in Aberdeen found that of 183 samples of milk 17 contained brucella abortus while Pullinger ${ }^{2}$ in 101 samples from 45 tested herds found brucella in 45 and it is generally recognized that epidemics of such diseases as scarlet fever, diphtheria and typhoid fever can arise from infected milk. It would appear, therefore, that it would be of advantage if, other things being equal, milk could be rendered free of pathogenic organisms. There are three main objections brought forward against sterilization of milk. It is urged that the universal adoption of sterilization by providing a germ-free supply would remove the incentive to the purchase of a high-grade supply from certified herds and that there would be no encouragement for farmers to go to the expense of maintaining such herds. It should, however, be possible to support the breeding of high-grade tubercle-free cattle and at the same time prevent the dissemination of disease by milk. Secondly it is held, and with justice, that germ-free milk does not necessarily mean either good-quality or even clean milk. The general public must be made to realize that three things are necessary for milk, (1) that it should be rich in fat and vitamins, (2) that it should not contain foreign material even if it is sterile, and (3) that it should be free of pathogenic organisms. Thirdly, it is maintained that sterilization alters the nutritive value of milk. This is the most fundamental objection and the following experiments are an attempt to throw light on this aspect of the problem.

In deciding whether or not sterilization alters the biological value of milk as a foodstuff for man it is preferable to test this on the human subject. If experimental animals are used it is essential that they should be observed during a period of life corresponding to that which it is desired to study in man. Even when the effect of sterilized milk is tested on the human subject it is necessary to take into account the possibility of natural fluctuations of growth unless large numbers are studied. Another source of error in such experiments occurs when the sterilized and raw milks do not come from the same source since the differences which may occur may be due not to differences in the treatment of the milks but rather to differences in their quality prior to any treatment which they may have undergone. 
Even when all these difficulties have been surmounted there is still to be faced the question as to what is to be the test of nutritive value. The best test is probably the rate of increase in height and weight but this cannot be taken as an index, since it varies from time to time and any investigation must include very large numbers in order to overcome these fluctuations. Even in large scale field experiments such as those in Lanarkshire and America difficulties have arisen both in their conduct and interpretation. Here the problem is approached from another angle and the attempt is made to discover if heat treatment of milk causes any alteration in the retention of minerals, nitrogen and fat. This test is at any rate as objective as can be devised but it is not to be inferred that nutrition can be gauged merely by the amounts of minerals and nitrogen that are retained. This procedure was adopted because few satisfactory experiments have been carried out on the human subject with the object of determining if heat treatment of milk causes any alteration in the retention of its constituents.

In a previous communication ${ }^{1}$ experiences with two infants fed exclusively on milk were reported. In it were given the results of balance experiments with raw and boiled milk respectively of one week's duration with suitable pre-periods. The retentions of calcium, phosphorus, nitrogen and fat were determined. Briefly, no evidence was obtained that the boiling of milk affected adversely the retention of these substances. Indeed, lower retention values for the first three were obtained while the infants were on raw milk; in the case of fat, the retentions were virtually the same. The object of the present communication is to record the results obtained from two older children who were on a diet not exclusively of milk.

\section{Method and results}

Two children of ten-and-a-half and seven-and-a-half years respectively were given the diet noted in table 1. About 50 per cent. of the caloric value of the diet and 70 per cent. of the total protein were supplied in the form of milk. The caloric intake as well as that of protein, minerals and fat was ample.

\section{TABLE 1}

JAmes S., aged 10 yr. 5 mth.; weight $26.6 \mathrm{kgm}$. Milk 1,250 c.c., sugar 44 gm., bread 120 gm., butter 10 gm., orange juice 30 c.c., banana 100 gm., water 300 c.c. (protein 57 gm., fat 57 gm., carbohydrate 194 gm.). Total intake 1,526 calories.

Peter T., aged 7 yr. 7 mth.; weight $23.2 \mathrm{kgm}$. Milk 1,000 c.c., sugar 44 gm., bread 120 gm., butter 10 gm., orange juice 30 c.c., banana 100 gm., water 300 c.c. (protein 48 gm., fat 47 gm., carbohydrate 182 gm.). Total intake 1,360 calories.

\begin{tabular}{|c|c|c|c|c|c|c|c|}
\hline \multicolumn{3}{|c|}{ Period ( 7 days) } & I & II & III & IV & $\mathrm{V}$ \\
\hline James S. & & $\ldots$ & $\begin{array}{l}\text { Boiled } \\
\text { milk }\end{array}$ & $\begin{array}{l}\text { Raw } \\
\text { milk }\end{array}$ & $\begin{array}{l}\text { Raw } \\
\text { milk }\end{array}$ & $\begin{array}{c}\text { Boiled } \\
\text { milk }\end{array}$ & $\begin{array}{c}\text { Boiled } \\
\text { milk }\end{array}$ \\
\hline Peter T. & & $\ldots$ & $\begin{array}{l}\text { Raw } \\
\text { milk }\end{array}$ & $\begin{array}{c}\text { Boiled } \\
\text { milk }\end{array}$ & $\begin{array}{c}\text { Boiled } \\
\text { milk }\end{array}$ & $\begin{array}{l}\text { Raw } \\
\text { milk }\end{array}$ & $\begin{array}{l}\text { Raw } \\
\text { milk }\end{array}$ \\
\hline
\end{tabular}




\section{EFFECT OF BOILING ON NUTRITIVE VALUE OF MILK 171}

Milk from the same source was utilized throughout the investigations. Juring the sterilized milk period, the milk was boiled for three minutes. Boiling was used in preference to commercial pasteurization in order to make certain that all the milk used came from the one source. After a period of not less than five days on the diet urine and faeces were collected for seven days. Thereafter the milk was changed from raw to boiled in one case and from boiled to raw in the other. This was continued for a fortnight when the milk was again changed to the first variety for another fortnight. Each child was, therefore, observed for a period of five weeks; (1) a week on raw or boiled milk, (2) two weeks on boiled or raw milk and (3) two weeks or. raw or boiled milk.

Calcium, phosphorus and nitrogen were estimated in the faeces, urine and aliquot portions of the various articles of the dietary. The fat content of the faeces and the diet was also determined. The results are given in tables 2 and 3.

TABLE 2 .

\begin{tabular}{|c|c|c|c|c|}
\hline \multirow{2}{*}{ Praiod, } & \multicolumn{3}{|c|}{ RETKNTIUN (MGM. PER KGM. PER DAY) } & \multirow{2}{*}{$\begin{array}{c}\text { Fat (PERCENTAGE } \\
\text { ABSORPTION). }\end{array}$} \\
\hline & $\mathrm{CaO}$ & $\mathrm{P}_{2} \mathrm{O}_{5}$ & $\mathrm{~N}$ & \\
\hline I. B. & $27 \cdot 9$ & $45 \cdot 9$ & $50 \cdot 3$ & $96 \cdot 4$ \\
\hline II. R. & $30 \cdot 1$ & $50 \cdot 2$ & $41 \cdot 7$ & $96 \cdot 9$ \\
\hline III. R. & $28 \cdot 2$ & $38 \cdot 4$ & $52 \cdot 6$ & $94 \cdot 5$ \\
\hline IV. B. & $3 \cdot 2 \cdot 2$ & $44 \cdot 8$ & $46 \cdot 4$ & $95 \cdot 7$ \\
\hline V. B. & $31 \cdot 7$ & $45 \cdot 0$ & $40 \cdot 0$ & $93 \cdot 6$ \\
\hline \multicolumn{5}{|c|}{ Averaties. } \\
\hline $\begin{aligned} & \text { I. } \text { B. } \\
& \text { II. } \text { R. } \\
& \text { III. } \text { R. } \\
& \text { IV. } \text { B. } \\
& \text { V. }\end{aligned}$ & $\begin{array}{l}27 \cdot 9 \\
29 \cdot 2 \\
32 \cdot 0\end{array}$ & $\begin{array}{l}45 \cdot 9 \\
44 \cdot 3 \\
44 \cdot 9\end{array}$ & $\begin{array}{l}50 \cdot 3 \\
47 \cdot 2 \\
43 \cdot 2\end{array}$ & $\begin{array}{l}96 \cdot 4 \\
95 \cdot 7 \\
94 \cdot 7\end{array}$ \\
\hline & $\mathrm{B}=\mathrm{E}$ & $\begin{array}{r}\text { TABLE } 3 \\
\end{array}$ & w $l ! i l$ & \\
\hline Perioj) & \multicolumn{3}{|c|}{ Rlitention (MGM. PER K(iM. PEK DAY) } & $\begin{array}{c}\text { Fat } \\
\text { (PrRceNtacie } \\
\text { A BSORPTION) } \\
\end{array}$ \\
\hline I. R. & $13 \cdot 5$ & $27 \cdot 1$ & $19 \cdot 6$ & $9.5 \cdot 5$ \\
\hline II. B. & $47 \cdot 3$ & $45 \cdot 7$ & $24 \cdot 2$ & $9 \mathrm{~s} \cdot 2$ \\
\hline III. B. & $-23 \cdot \overline{5}$ & $1 \cdot 8$ & $15 \cdot 1$ & $91 \cdot 9$ \\
\hline IV. R. & $43 \cdot 9$ & $25 \cdot 4$ & $19 \cdot 3$ & $98 \cdot 0$ \\
\hline V. R. & $-11 \cdot 9$ & $23 \cdot 1$ & $18 \cdot 1$ & $92 \cdot 9$ \\
\hline \multicolumn{5}{|c|}{ Averagis } \\
\hline I. R. & $13 \cdot 5$ & $27 \cdot 1$ & $19 \cdot 6$ & $95 \cdot 5$ \\
\hline 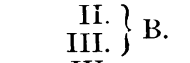 & 119 & $23 \cdot 8$ & $19 \cdot 4$ & $95 \cdot 1$ \\
\hline $\left.\begin{array}{r}\text { IV. } \\
\text { V. }\end{array}\right\} \mathrm{R}$. & $16 \cdot 0$ & $24 \cdot 3$ & $18 \cdot 7$ & $95 \cdot 5$ \\
\hline
\end{tabular}




\section{Comment}

With James S. the retentions of phosphorus, nitrogen and fat showed no significant variations during the whole period of observation. Calcium retention showed a slight increase during the last two weeks on boiled milk. With Peter T., however, it will be observed that the change from raw to boiled and from boiled to raw milk produced in each case a great increase in the retention of calcium and phosphorus due to a great decrease in faecal output. This increased retention was only apparent as it was counterbalanced by the increased faecal output during the succeeding week. When the raw milk results are taken together and compared with the figures obtained during the two weeks on boiled milk it is clear that the retention of $\mathrm{CaO}$ and $\mathrm{P}_{2} \mathrm{O}_{5}$ during the consumption of boiled milk is only slightly lower than when raw milk was taken. It would appear that the change from raw to boiled milk and vice versa led to temporary periods of constipation. This is an observation which requires to be emphasized in the performance of retention experiments. It is generally held that a period of a week is sufficient for the determination of retention. These observations indicate that in some cases a fortnight may be necessary in order to prevent a temporary alteration producing a fallacious result.

In testing the value of sterilized milk in a mixed dietary it is necessary to make clear various methods which may be used. In the first place the milk may form either the main part or only a small fraction of the diet. Secondly, the total intake of one or more constituents of the diet may be ample or barely sufficient. Thirdly, the period of observation may be relatively short over a period of a few weeks or extend for months or years.

The results recorded here indicate that there is no evidence that over short periods the boiling of milk impairs either its absorption or utilization, when there is an ample supply of proximate principles and minerals and when the caloric intake is adequate. It still remains possible that over long periods or/and when the intake is no more than sufficient, the sterilization of milk might make a difference to the retention of essential substances. So far, however, satisfactory proof of this is lacking.

\section{REFERENGES}

1. Morris, N., \& Graham, S., Lancet, London, 1933, ii, 1314.

2. Pullinger, E. J., ibid., 1934, i, 967.

3. Smith, J., Journ. Hyg., London, 1934, XXXIV, 242. 